\title{
Central Europe as a space of transnational migration
}

\section{An introduction to the contributions in this issue}

\author{
Max Haller · Roland Verwiebe
}

Published online: 5 December 2016

(C) Springer Fachmedien Wiesbaden 2016

Migration is one of the most challenging scientific and policy issues today. In recent times, it showed up in dramatic events and led to significant changes of the political landscape in Europe. The most dramatic phenomenon was the flow of over a million refugees in 2015 and early 2016 from war-torn countries in the Near East (Syria, Afghanistan and Iraq), over Turkey, Greece, the Balkan states and Hungary toward Austria, Germany and Sweden; over 3000 people died when crossing the Mediterranean Sea from Turkey to Greece. In the months of the arrival of the Near-East refugees in Austria and Germany in late 2015, popular attitudes to accept and provide them with shelter and food was overwhelming, supported by the political decision to open the borders for them; in recent times, however, popular attitudes have changed and German chancellor Angela Merkel who gained worldwide publicity and sympathy with her sentence "Wir schaffen das" (We will achieve this) now faces the danger of losing a larger share of her voters at the next national elections. Second, we can observe a continuous rise of right-wing and farright political parties in at least half of the EU member states. This is the case most notably in Austria, Switzerland, France, Hungary and Poland, but takes place also in Scandinavia. ${ }^{1}$ All these parties argue for a limitation of immigration, a reduction

\footnotetext{
1 An overview on the single countries was given in The New York Times (5. 7. 2016) in: "How Far Is Europe Swinging to the Right?"; see https://www.google.at/?gws_rd=ssl\# q=right+wing+political+parties+europe.
}

M. Haller $(\bowtie)$

Simmeringer Hauptstr. 54, 1110 Wien, Austria

E-Mail: max.haller@uni-graz.at

R. Verwiebe

Institut für Soziologie, Universität Wien, Rooseveltplatz 2, 1090 Wien, Austria

E-Mail: roland.verwiebe@univie.ac.at 
of benefits for immigrants and refugees, and a preferential treatment of national citizens on the labor market. A third significant event was the Brexit when $51.9 \%$ of the Britons voted to leave the European Union (EU) on June 23, 2016; in this vote, the issue of immigration played a central role. A reason was that Britain was among those countries which opened their labor market immediately after the accession of ten Eastern European countries to the EU in 2004. As a consequence, a massive influx of immigrants from there took place (alone from Poland about 600,000); of the 2.1 million EU citizens living in Britain, most are from Central and Eastern Europe as well as from Portugal, France and Spain. ${ }^{2}$

However, migration and immigration has been taking place in Europe - and in the world as a whole - since centuries. In recent times, it has reached an unprecedented scale. It has been estimated that in 1960, 76 million people were on the way to, or living as migrants in another state; this number increased continuously until 2005 up to 191 million (Castles and Miller 2009, p. 5); the estimated figure for 2015 is 244 million (IOM 2015). The increase has been largest in Europe, however, here the number of migrants increased from 14 million in 1960 to 64 million in 2005 - more than a fourfold increase. The increase was connected with a significant change in the patterns and forms of migration. In the first decade after World War II, a significant influx of immigrants took place from former colonies to France, the Netherlands and the United Kingdom. In the next period, the late 1960s and 1970s, the predominant form was that of Gastarbeiter, that is movements of typically male workers from South European countries - Italy, Spain, Portugal - and from Turkey and Morocco toward Central and North Europe - Switzerland, Germany, the Benelux countries and Scandinavia; the receiving countries actively encouraged and promoted this kind of movements in order to get laborers for their expanding industrial production and service sector. It was expected that the workers would return home when their labor was no longer needed. However, this did not happen and most of the immigrants settled down in the receiving countries, bringing with them also their family members.

The fall of the Iron Curtain between Eastern and Western Europe in 1989 and the breakdown of the state socialist regimes in Central Eastern Europe and the Soviet Union brought a new impetus for migration. The closure of many unprofitable stateowned enterprises, the increasing unemployment and the abolition of the former restrictions on emigration led to a new and massive emigration from Central Eastern Europe toward West and South Europe. In this process, the migration regimes of the South European countries underwent a total change: Their character changed from emigration to immigration countries. Here, both male and female migration from East to West and South Europe took place with the migrant women employed in cleaning and household services, as well as care, and men in agriculture, construction and industry. This movement was further stimulated by the accession to the European Union of eight Central Eastern European countries in 2004 and in 2007 of Bulgaria and Romania. Given the high discrepancies in the mean wages in Western and Eastern Europe, it was expected that a large migration wave from East to West would emerge. Therefore, in a few EU member states, including Austria and Germany,

\footnotetext{
${ }^{2}$ See http://time.com/4357815/eu-britain-migrant-referendum-brexit-wisbech/.
} 
a transition period was introduced during which worker immigration from the East was regulated and limited. Although factual immigration was lower than predicted, nevertheless a massive population movement took place. Between 1990 and 2015, nearly 20 million people left Central Eastern Europe, leading to a significant decline of population in several countries of the region, and a strong increase of foreigners and foreign-born people in Western Europe (Atoyan et al. 2016). It is evident that this migration mainly supported economic development in Western Europe, while it became detrimental for Eastern Europe in several regards: Since especially young and better educated people are inclined to emigrate, they are missing in their home countries not only for demographic reproduction, but also in several sectors of employment, particularly care and health sectors. About half a million children may have been left with their grandparents or other relatives because the parents are working most of the year in a West European country. ${ }^{3}$ The economic consequences for the Eastern European countries have been summarized in a recent IMF report as follows: "The drain of skilled labor has lowered productivity growth and pushed up wages, undermining competitiveness. And although remittances have supported consumption and investment, and helped deepen banking systems in some countries, they may also have reduced incentives to work" (Atoyan et al. 2016, p. 30).

Austria has been affected by all these structural changes and processes in a particular way. Located at the direct intersection between South and North, and West and East Europe, it was a target of immigration during the 1960s and 1970s from Italy, Yugoslavia (which did not restrict emigration like the other state socialist countries) and Turkey; after the fall of the Iron Curtain, about 90,000 war refugees from Bosnia-Herzegovina arrived in Austria, and later on, a wave of new immigration started from Hungary and most countries of former Yugoslavia. In the course of these processes, Austria itself has changed its role from that of an emigration to an immigration country. In the Gastarbeiter period (about 1960 to 1975), some hundred thousands of persons left Austria for better paid work in Switzerland and Germany, while since 1990 significant immigration occurs even from Germany (particularly from the new federal states in East Germany), making German nationals today the largest group of foreign nationals in Austria (see Table 1; see also Fassmann and Münz 1995; Bauer 2008).

The largest share of immigration to Austria, however, is from the neighboring Eastern European countries. As a consequence of all the aforementioned immigration streams, the proportion of foreign-born population in Austria is one of the highest in the European Union: $16.6 \%$ in 2014 (Table 1). A total of $21.3 \%$ of the Austrian population have a migration background, that is, they themselves or their parents have been born in another country (Migration und Integration 2017, p. 23). By comparison, in most Central Eastern European countries it is below 5\%. To investigate migration to Austria from its neighboring countries is also fascinating because many of them were united through centuries in the Austro-Hungarian monarchy.

\footnotetext{
3 See, for instance, the report of the German newspaper Die Welt am Sonntag with the title "Abwanderung ist für den Osten eine Katastrophe" (Emigration is a catastrophe for the East); available at https://www. welt.de/politik/ausland/article124377169/Abwanderung-ist-fuer-den-Osten-eine-Katastrophe.html.
} 
Table 1 Socio-economic characteristics of populations and immigrants in eight Central European countries (2014-15)

\begin{tabular}{|c|c|c|c|}
\hline $\begin{array}{l}\text { Country (population } \\
2015 \text { in millions) }\end{array}$ & $\begin{array}{l}\text { Mean income per } \\
\text { head (Euro/year) }\end{array}$ & $\begin{array}{l}\text { Percent foreign- } \\
\text { born population }\end{array}$ & $\begin{array}{l}\text { Foreign born: main countries } \\
\text { of origin (in } 1000 \mathrm{~s} \text { ) }\end{array}$ \\
\hline Germany (82.1) & 22,537 & 12.2 & $\begin{array}{l}\text { Turkey (1372), Poland (640), } \\
\text { Italy (537), Romania (345), } \\
\text { Greece (304) }\end{array}$ \\
\hline Austria (9.7) & 26,080 & 16.6 & $\begin{array}{l}\text { Germany (170), Serbia (113), } \\
\text { Turkey (115), Bosnia-Herz. } \\
\text { (92), Romania (71) }\end{array}$ \\
\hline Poland (34.8) & 6163 & 1.6 & $\begin{array}{l}\text { Ukraine (20), Germany (6), } \\
\text { Belarus (5), Russia (5) }\end{array}$ \\
\hline $\begin{array}{l}\text { Czech Republic } \\
\text { (11.0) }\end{array}$ & 8600 & 3.8 & $\begin{array}{l}\text { Ukraine (108), Slovakia (96), } \\
\text { Vietnam (57), Russia (34) }\end{array}$ \\
\hline Slovakia (4.8) & 7484 & 3.2 & $\begin{array}{l}\text { Czech Rep. (11), Hungary (8), } \\
\text { Poland }(5)^{\mathrm{a}}\end{array}$ \\
\hline Hungary (9.3) & 5124 & 4.5 & $\begin{array}{l}\text { Romania (28), Germany (18), } \\
\text { China (16) }\end{array}$ \\
\hline Croatia (3.8) & 5799 & $0.8^{\mathrm{a}}$ & $\begin{array}{l}\text { Foreign citizens of: Bosnia- } \\
\text { Herz. (6), Serbia (2), Slovenia } \\
\text { (2) } \\
\text { Ethnic groups (2011): Serbs } \\
\text { (186), Bosniaks (31), Albani- } \\
\text { ans (17), Italians (17) }\end{array}$ \\
\hline Slovenia (2.0) & 12,843 & $4.7^{\mathrm{a}}$ & $\begin{array}{l}\text { Bosnia-Herzegovina (44), } \\
\text { Kosovo (12), Serbia (9) }\end{array}$ \\
\hline
\end{tabular}

Sources: Mean income per head 2014 (net equivalence income, standardized by household composition): WKO (Wirtschaftskammer Österreich [http://wko.at/statistik/eu/europa-einkommenarmut.pdf]); percent foreign-born 2015: Eurostat, Table "Migration and migrant population statistics" (http://ec. europa.eu/eurostat/statistics-explained/index.php/Migration_and_migrant_population_statistics); Croatia and Slovenia: eurstat newsrelease 230/2015 (http://ec.europa.eu/eurostat/documents/2995521/7113991/318122015-BP-EN.pdf/d682df12-8a77-46a5-aaa9-58a00a8ee73e).

${ }^{a}$ Foreign citizens

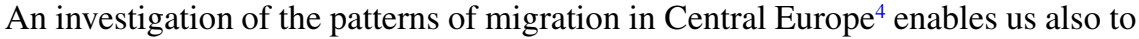
test and evaluate different theories of migration and hypotheses about factors which have an effect on migration patterns. We can mention here at least four general factors connected to some degree with specific theoretical approaches: Gaps in income and standards of living; territorial affiliation and geographical proximity; ethniccultural factors; and the role of politics, border control and migration management. The papers in this issue are concerned with these aspects from several perspectives.

The well-known thesis developed by neoclassical economic theories of migration is that migration is the consequence of push and pull factors, such as employment and income opportunities, and differences in standards of living, and in political freedom or repression (see Massey et al. 1993; Castles and Miller 2009, p. 22 ff.).

\footnotetext{
4 The term "Central Europe" has varying meanings and it is also politically biased to some degree (either from the perspective or German ideas of hegemony or from the perspective of nostalgia for the old AustroHungarian empire). We do not identify with any of these views but use the term here in a value-free sense, including countries in the geographic centre of Europe.
} 
It is assumed that individuals evaluate their life situation through a cost-benefit analysis and will move if the expected gains are larger than the costs associated with movement to another country. The main factor upon which economists rely on is gaps in income between different countries and regions. One could argue, however, that income is also a central sociological variable since it provides the basis for the living standard and lifestyle, and that the level of income also constitutes a status symbol. Thus, we do not see, as is usually the case, a fundamental difference between economic and sociological theories in this regard, although we would also always include structural and institutional aspects into an explanation. Thus, we agree with economists that expected higher incomes in countries of destination may induce people to move toward those countries. This factor must evidently be of high importance in the case of the Central European macroregion where large differences in personal income exist. Table 1 shows that the income per head in Austria is the double of that in Slovenia (this country has already a higher mean income than Greece and Portugal), three times as high as in Hungary and Slovakia, about four times as high as in Croatia, Hungary and Bulgaria, and ten times as high as in Romania. ${ }^{5}$

However, the economic explanation cannot be the only one: the largest numbers of people from the low-wage Central Eastern European countries do not emigrate as is the case in every other country around the world; people who move within the European Union do so mainly within their own countries (Hadler 2006). In order to understand this fact, we must supplement the focus of economic theories on individual decisions with two additional perspectives: First, with a focus on structural factors, including territorial affiliation and geographical proximity, and ethnic-cultural factors. One aspect which is central in sociological theories of migration are social networks which migrants form in the immigration countries and between these and their home countries (Han 2010; Verwiebe et al. 2015a). After a certain number of immigrants from a specific country have settled down in a destination country, they often induce kinsmen, friends or neighbors to follow them. This explains why in certain towns and regions in immigration countries persons from certain countries of origin are dominant. An important structural aspect to be considered here is that of territory and geography. It is much easier to cross the border between, for instance, Slovakia, Hungary and Croatia on the one side, and Austria on the other side because they are direct neighbors, than, for instance, to emigrate to Scandinavia, not to speak of America or Australia, which in former times were the most important targets of European emigration. Looking at immigrants from Central Eastern Europe, we can recognize the relevance of this factor also in Table 1: it shows that Germany is mainly important as a destination country for immigrants from neighboring Poland, whereas Austria is important for people from the countries of former Yugoslavia.

Second, we must also develop a more complex view of the process of migration from the perspective of time. Today, migration is not any more a simple process,

\footnotetext{
5 Data on working incomes (wages and salaries) in the EU member countries show lesser differences; but also in these data incomes in Austria are two to three times as high as in Poland, the Czech Republic and Hungary.
} 
involving a single and definite decision to move to another country, and to settle there forever; rather, it involves several stages of moving to another place, staying there for shorter or longer periods of time, and moving back to the home country or moving back and forth between countries. These processes are supported by modern means of communication and much more efficient means of traffic and transport.

The issues raised by these concepts and approaches are covered by the contributions in this volume in several regards. The question of the relevance of income differences for migration is investigated by Miloslav Bahna in his article entitled "Ten years after the post accession migration wave from EU 8 to the UK: What can we learn from the largest intra-EU migration experiment?" His analysis at the aggregate level shows a strong correlation between average wages in the Central Eastern European countries and the emigration to the UK (considered in relative terms in proportion to population size of the respective countries): Slovenia has the highest wages and the lowest proportion of emigrants to the UK; Latvia and Lithuania have the lowest national wages and the highest emigration quota; most other countries (except Hungary with a relatively lower emigration rate) lie on a regression line in between. Miloslav Bahna finds that this economic explanation has not lost power through the entire period between 2004 and 2014, despite a slowing down of emigration between 2005 and 2008, and a significant decrease since 2011.

In her contribution entitled "A preferred labour force? Employment practices in the low-wage sector of the Austrian border region concerning commuters from Czech Republic, Hungary and Slovakia”, Laura Wiesböck looks at the closely integrated macroregion covering the border area of Austria, the Czech Republic, Slovakia and Hungary which includes the cities of Vienna, Brno, Bratislava and Györ. In this region, a considerable amount of cross-border commuting takes place whereby people work in Austria without moving their residence to this country. In this way, they can profit from the lower costs of living in their countries and from the higher wages in Austria. Official statistics counted around 147,000 such in-commuters in Austria; most of them came from Hungary $(37,000)$, Slovakia $(34,000)$ and Germany $(26,000)$; they work mostly in personal services and care, the hotel and restaurant industry, in construction and building and in agriculture. ${ }^{6}$ What is very interesting and new in the analysis of Laura Wiesböck, based on twenty expert interviews, is the finding that employers play a significant role in this process of transnational commuting: The workers from the other side of the border are welcomed by them and even preferred to Austrian nationals also applying for jobs because the employers made the experience that the foreign workers were more willing to work hard and are more reliable and obedient. These traits seemed to outweigh their lack of self-initiative also observed by the employers. This finding is well in line with the observation that Austrian employer associations frequently complain about a shortage of qualified workers (Heschl 2009) - in spite of the fact that unemployment is continuously increasing in Austria since the 1980s from only 50,000 at that time (an unemployment rate of less than 2\%) up to 323,000 persons in 2016 (unemployment rate of $6 \%$ ); this large reservoir of unemployed people certainly also includes many

\footnotetext{
${ }^{6}$ Reported in Die Presse, see http://diepresse.com/home/wirtschaft/economist/4831248/Arbeitsmarkt_ Ansturm-der-Osteuropaer.
} 
skilled workers. This finding also contradicts the frequent assertion that many immigrants and refugees are only looking to capitalize the well-developed welfare state supports in countries like Austria, Germany or Sweden. The competition between national and foreign job applicants for jobs in the low-wage sector also contributes to a repression of wages for less skilled work and a potential undercutting of standards of labor safety and quality. Laura Wiesböck concludes that "persisting inequalities between commuters and locals will pose a serious threat to cohesion in the receiving states ...".

The issue of transnational migration between adjacent countries is also investigated in the paper by Saša Božić and Simona Kuti entitled "New international borders - old social spaces: transnational migrant networks across the boundaries of post-socialist Croatia”. This paper also shows the effects of the territorial and of ethnic and cultural factors on patterns of migration. The Balkan region had a similar fate after World War II as Austria had after World War I: The multiethnic and multicultural state of Yugoslavia broke down from 1990 on and seven new nation states were established which are - with the exception of Bosnia-Herzegovina more homogeneous in ethnic terms. The former state of Yugoslavia was a rather open and unified market with considerable internal migration which resulted in the erection of nationwide family and ethnic networks. The internal openness and circulatory migration was permitted and even fostered by the Communist Party in order to bring about a new "Yugoslav" national consciousness, independent of regional ethnic affiliations. However, the networks spanning over the different republics were mainly developed among members of the same ethnic-regional groups. Particularly the Bosniak and Albanian migrants in Slovenia and Croatia developed extensive networks which in many cases included also emigrants living in Austria, Germany and Sweden. The level of economic development - significantly higher in Slovenia and Croatia compared to the Central and Southern republics - determined the direction of migration which was going mainly from South to North. The same was true for Croatian and Serbian migrants to Austria and Germany many of whom settled permanently there, in spite of the aims of the Gastarbeiter policy of these countries. Thus, they became a new sort of "transmigrants", in some way forerunners of a new type of "transnationalism" (Glick Schiller et al. 1992; Faist 2000). The dissolution of Yugoslavia, following the wars in Croatia, Bosnia-Herzegovina and Kosovo, reinforced the older patterns of transnational migrant networks; the access of Croatia to the European Union in 2013 facilitated new labor migration. However, many of these emigrants continue to keep close ties with their home countries and regions: For instance, they build or buy houses on the Adriatic coast for tourists which family members and relatives help to maintain. Saša Božić and Simona Kuti write in this regard: "Bosniak interviewees described strong and numerous family relations, connecting persons in Croatia with their family members in Bosnia and Herzegovina and elsewhere. Contact is maintained through (mobile) phones, Skype, MSN and Facebook, particularly among the younger interviewees ... geographic proximity of Croatia and Bosnia and Herzegovina enables frequent mobility and visitation, facilitating strong family ties ..." This may apply also to migrants from former Yugoslavia, Hungary and the Czech Republic now living in Austria and Germany. 
The territorial-spatial aspect of migration is covered in the paper by Dusan Drbohlav entitled “'A new song or evergreen ...?' The spatial concentration of Vietnamese migrants' businesses on Prague's Sapa site”. In this paper, a peculiar site of the Czech capital Prague is investigated, namely a former industrial compound which was utilised by about 350 Vietnamese and other Asian small traders, restaurant owners and other entrepreneurs starting in the early 1990s. It was then transformed into a well-functioning business compound (called the Sapa site), surrounded by a gate but open to the public. Looking at Central Eastern Europe as a whole, this is certainly a unique place. Immigration from Vietnam to Czechoslovakia was officially encouraged in former times, based on the common state socialist political ideology; still today, nearly 60,000 Vietnamese people are living in the Czech Republic, constituting the third largest immigration group in this country (see Table 1). Dušan Drbohlav investigates the question if the Sapa compound corresponds to similar ethnic suburban settlements found elsewhere or if it exhibits specific characteristics. He finds that, in fact, the Sapa site does not correspond to settlement models described for the USA, but corresponds more to similar formations in other Central European cities, such as Berlin, Warsaw or Bratislava. They all "were formed in a specific time period and in a specific transformatory post-communist region". The Sapa site did not emerge as a consequence of a concentration of a specific ethnic group in a suburb, or as an ethnic market or the like, but was formed primarily on the basis of the economic functions provided. Thus, again, we have an instance confirming the thesis that Central Europe constitutes a peculiar transnational space of migration and integration. Compared to cities in France, the UK and the United States, ethnic segregation seems to be lower in Central European Cities, including Vienna in spite of its huge immigration in recent decades.

What can we conclude from the facts and trends outlined above concerning the relevance of politics, state borders and management of migration? Considered at a specific point of time, it may in fact be an illusion to assume that the EU and its member states can really control immigration flows (Fassmann and Lane 2009, p. 2). Seen from a wider historical perspective, however, it is evident that politics has an immense impact on scale and patterns of migration. This is most evident if we look at politically induced wars and their consequences. All major wars in Europe led to massive population movements: after the First and Second World Wars millions of people had to change where they lived, including more than 12 million Germans who had to move from former German territories toward the West; Russians settling on the territories of former Eastern Poland; German-speaking Austrians from the nonGerman territories of the Austro-Hungarian empire toward Austria and Germany; Greeks from Turkey to mainland Greece, and Turks the other way around. The post-war South-North Gastarbeiter migration was induced to a large degree by political decisions and supporting measures. In recent times, the emergence of a new East-West migration in Europe was due to the downfall of the Iron Curtain and the communist Eastern European regimes. The economic backwardness of these countries motivated many people to emigrate. But these movements were also strongly supported by the fast acceptation of the Central Eastern European countries into the EU and the subsequent opening of western labor markets. Thus, in a more 
long-term view, politics evidently has a massive impact on patterns and flows of migration.

Which conclusions can we draw from these findings for present-day politics? Given the developments outlined above, one could argue that the accession of the Eastern European countries to the EU and the opening of the EU labor markets happened too fast. This argument is not very useful for tackling present-day problems. Nevertheless, we have no doubt that in spite of all problems today associated with the massive East-West migration, the present situation is by far preferable to that of a few decades ago when Western and Eastern Europe were separated by a wall insuperable for people in the East.

However, the problems associated with the recent migration to which we have pointed - including the rise of right-wing populist political parties in West Europe - make clear that definite measures must be taken in order to come to grips with its problematic consequences. In Austria, Germany and other Central European countries, provisions must be taken to prevent the emergence of a split labor market within unskilled, manual and service work with the consequence of an undermining of labor standards, an increase of economic inequality and potential disruptive conflicts; such conflicts predominate in a fateful way in African and Latin American societies with a clearly discernible ethnic stratification (Haller and Eder 2015). In recent decades, public opinion and politics in Austria have to some degree changed their earlier view of Austria as "an immigration country against one's will" (Fassmann and Münz 1995) toward the one which needs immigration and clearly profits from it. It is also a positive aspect that in the papers in this issue no ethnic-national conflicts between immigrants and natives were reported. This might be due, first, to the fact that such differences (except those of language) are not very pronounced in Central Europe; and second, to the fact that many immigrants do not plan to settle permanently in the immigration countries. However, in times of economic slowdown and increasing unemployment negative attitudes to immigration and xenophobic stereotypes may be on the rise again (see Verwiebe et al. 2015b).

Finally, there is still much to be achieved in regard to the integration of immigrants and their children in terms of equal opportunities in the educational system and in the labor market in Austria and other Central European immigration countries. While most immigrants feel quite satisfied with their life in Austria, and many of them (and their children) are able to advance in educational and occupational terms, in relative terms they still lag behind the Austrian population (Migration und Integration 2016). As far as the Central Eastern European countries are concerned, it seems very important that they take measures to retain particularly skilled and highly educated workers needed for their own economy and society (see also Atoyan et al. 2016). Measures required to achieve this aim include fair salaries, but also the reform of many institutions in a way that they can operate more efficiently without political interference and corruption. Eastern European governments should also encourage emigrants needed for their own economies to return home and they should concentrate their efforts on creating attractive employment opportunities for their youth. Cities like Vienna and Berlin are highly attractive places to work and live; perhaps some of the business, technical and scientific activities in these cities 
in which people from Central Eastern Europe also participate, could be carried out in Zagreb, Budapest or Prague.

Acknowledgements Thanks for very useful comments to this introduction are given to Franz Höllinger.

\section{References}

Atoyan, Ruben, et al. 2016. Emigration and its economic impact on Eastern Europe. IMF Discussion Note. Washington, D. C.: International Monetary Fund.

Bauer, Werner T. 2008. Zuwanderung nach Österreich. Wien: Österreichische Gesellschaft für Politikberatung und Politikentwicklung (ÖGPP).

Castles, Stephen, and Mark J. Miller. 2009. The Age of Migration. International Population Movements in the Modern World. Houndmills: Palgrave.

Faist, Thomas. 2000. Transnationalization in international migration: Implications for the study of citizenship and culture. Ethnic and Racial Studies 23:189-222.

Fassmann, Heinz, and David Lane. 2009. Migration and mobility in Europe: an introduction. In Migration and Mobility in Europe, ed. Heinz Fassmann, Max Haller, and David Lane, 1-11. Cheltenham: Edward Elgar.

Fassmann, Heinz, and Rainer Münz. 1995. Einwanderungsland Österreich? Historische Muster, aktuelle Trends und politische Maßnahmen. Wien: Jugend \& Volk.

Glick Schiller, Nina, et al, 1992. Towards a transnational perspective on migration. Annals of the New York Academy of Sciences 645:1-24.

Hadler, Markus. 2006. Intentions to migrate within the European Union: A challenge for simple economic macro-level explanations. European Societies 8:111-140.

Han, Petrus. 2010. Soziologie der Migration. Erklärungsmodelle, Fakten, politische Konsequenzen, Perspektiven. München: Lucius/UTB.

Heschl, Franz. 2009. Shortage of skilled workers: myths and realities. In Migration and Mobility in Europe, ed. Heinz Fassmann, Max Haller, and David Lane, 31-50. Cheltenham: Edward Elgar.

Haller, Max, and in collaboration with Anja Eder. 2015. Ethnic Stratification and Socioeconomic Inequality around the World. The End of Exclusion and Exploitation? Farnham: Ashgate.

International Organisation for Migration. 2015. World Migration Report. Geneva: IOM. https://www.iom. int/world-migration-report-2015.

Massey, Doug S., et al. 1998. Worlds in Motion: Understanding International Migration at the End of the Millennium. Oxford: Clarendon Press.

Statistik Austria. 2016. Migration und Integration. Zahlen - Daten - Indikatoren. Wien: Statistik Austria, Österreichische Akademie der Wissenschaften.

Statistik Austria. 2017. Migration und Integration. Zahlen - Daten - Indikatoren. Wien: Statistik Austria, Österreichische Akademie der Wissenschaften.

Verwiebe, Roland, Christoph Reinprecht, Raimund Haindorfer, and Laura Wiesböck. 2015a. How to Succeed in a Transnational Labor Market. Job Search and Wages among Hungarian, Slovak and Czech Commuters in Austria. International Migration Review 49:1-36. doi:10.1111/imre.12193.

Verwiebe, Roland, Raimund Haindorfer, Cornelia Dlabaja, and Sina Lipp. 2015b. Zusammenleben in Wien. Einstellungen zu Zuwanderungen und Integration. Werkstattbericht, Vol. 152. Wien: Magistratsabteilung 18 für Stadtentwicklung und Stadtplanung. https:/www.wien.gv.at/stadtentwicklung/ studien/pdf/b008430.pdf.

Max Haller $(* 1947)$ is professor emeritus of Sociology from the University of Graz and a member of the Austrian Academy of Sciences. His research areas include social inequality, European integration, comparative analyses with survey data and sociological theory. His recent publications are: European Integration as an Elite Process (Routledge 2008); Ethnic Stratification and Income Inequality around the World (with Anja Eder; Ashgate 2015); Higher Education in Africa. Findings and Challenges for Development, Mobility and Cooperation, edited with Anne Goujon and Bernadette Müller-Kmet (Cambridge Scholars Publishing; in print). 
Roland Verwiebe $(* 1971)$ is a Full Professor of Social Stratification Research and Quantitative Methods at the University. His main research interests cover topics such as social inequality, migration, labor market and European integration. Recent publications include: Roland Verwiebe (2011) (Ed.): Armut in Österreich [Poverty in Austria]. Vienna: Braumüller; Steffen Mau/Roland Verwiebe (2010): European Societies. Mapping Structure and Change. Bristol: Policy Press; various recent contributions to peerreviewed journals such as European Journal of Sociology, European Journal of Social Policy, International Migration Review, International Migration. 